\title{
Renin and Aldosterone Measurements in the Management of Arterial Hypertension
}

Authors

Affiliations
A. Viola ${ }^{1}$, S. Monticone ${ }^{1}$, J. Burrello ${ }^{1}$, F. Buffolo ${ }^{1}$, M. Lucchiari ${ }^{2}$, F. Rabbia' ${ }^{1}$, T. A. Williams ${ }^{1}$, F. Veglio', G. Mengozzi ${ }^{2}$, P. Mulatero

${ }^{1}$ Division of Internal Medicine and Hypertension, Department of Medical Sciences, University of Torino, Torino, Italy ${ }^{2}$ Clinical Chemistry Laboratory, University of Torino, Torino, Italy
Key words

- arterial hypertension

- rennin

- aldosterone

- Laragh's hypothesis

- therapy received 23.07.2014

accepted 12.03.2015

\section{Bibliography}

DOI http://dx.doi.org/

10.1055/s-0035-1548868

Published online:

May 8, 2015

Horm Metab Res 2015;

47: 418-426

(c) Georg Thieme Verlag KG

Stuttgart · New York

ISSN 0018-5043

\section{Correspondence}

\section{A. Viola}

Division of Internal Medicine and Hypertension

Department of Medical

Sciences

University of Torino

Via Genova 3

10126 Torino

Italy

Tel.: + 39/011/6336959

Fax: + 39/011/6336931

andreaviola.83@gmail.com

\section{Abstract \\ $\nabla$}

Renin-angiotensin-aldosterone system (RAAS) is recognized as the main regulatory system of hemodynamics in man, and its derangements have a key role in the development and maintenance of arterial hypertension. Classification of the hypertensive states according to different patterns of renin and aldosterone levels ("RAAS profiling") allows the diagnosis of specific forms

\section{Introduction}

$\nabla$

Since the discovery of renin in 1898 by Tigerstedt [1], our comprehension of the renin-angiotensinaldosterone system (RAAS) has grown progressively [2,3] and this hormonal cascade is now recognized as the main regulatory system of hemodynamics in man.

According to Poseuille's law, the main determinants of pressure in a hydraulic system are the overall resistance of the conduit and the fluid flow passing through it. Considering the vascular system, these factors consist of vascular resistance, due to systemic vascular tone, and cardiac output, which is directly related to preload and, hence, to blood volume, respectively. Several important mechanisms and physiological systems have been implicated in the control of blood pressure (BP) levels both in the short- and longterm [2]. In the steady state, however, the key role of the RAAS has been demonstrated, as it can affect both peripheral vascular resistance and kidney sodium handling and, therefore, circulating volume. In fact, on the one hand angiotensinII is itself a vasopressor agent and is able to stimulate the secretion of another potent endogenous vasopressor, arginine-vasopressin. On the other hand, angiotensin-II directly enhances sodium reabsorption in the proximal tubule and stimulates the production of aldosterone, that is of secondary hypertension and may identify distinct hemodynamic subsets in essential hypertension. In this review, we summarize the application of RAAS profiling for the diagnostic assessment of hypertensive patients and discuss how the pathophysiological framework provided by RAAS profiling may guide therapeutic decision-making, especially in the context of uncontrolled hypertension not responding to multi-therapy.

responsible for sodium reabsorption in the distal tubule [4]. Besides this classical view of the RAAS, several experimental studies on animal models have established the involvement of a local brain RAAS in the regulation of BP through central modulation of sympathetic efferents, baroreceptor reflex mechanisms, and renal tubular reabsorption $[3,5]$.

As previously stated, the main determinants of BP levels are vascular tone (the "resistance", or "R-factor") and circulating volume (the "volume", or "V-factor"). Owing to the RAAS, these 2 factors are reciprocally regulated. Physiologically, in fact, hypovolemia triggers renin secretion, resulting in angiotensin-II-mediated vasoconstriction and angiotensin-II- and aldosterone-mediated sodium reabsorption, whereas increased circulating volume downregulates renin release and angiotensin-II generation, preventing further sodium reabsorption and especially decreasing peripheral vascular resistance.

Circulating volume can primarily increase irrespective of activation of the renin-angiotensin-II axis (e.g., due to excessive sodium intake or primary aldosteronism), and this leads to renin suppression. In contrast, vascular tone in the steady state is mainly related to angiotensin-II-dependent vasoconstriction and, therefore, to renin activity. For these reasons, renin levels somehow may represent vascular tone ("R-factor") whereas 
Beyond "true" high-renin secondary forms of hypertension, it should not be forgotten that coexistence of high blood pressure and high renin levels may also often occur in the uncontrolled hypertensive treated with angiotensin-converting enzyme inhibitors (ACEi) and angiotensin-II receptor blockers (ARBs). These drugs, in fact, remove the negative feedback loop exerted by angiotensin-II on renin secretion and plasma renin activity by blocking production of angiotensin-II or its binding to angiotensin-II receptors type 1 ( $\left.\mathrm{AT}_{1}-\mathrm{Rs}\right)$. A correct interpretation of high renin levels in a hypertensive patients should then always prompt an evaluation of the ongoing medications.

\section{Low-renin hypertensive states}

Low-renin hypertension encompasses about $30 \%$ of hypertensive patients [10] and a number of secondary causes of hypertension falls into this group. In fact, all monogenic forms of hereditary hypertension so far discovered are related to renal electrolyte handling and determine an excessive sodium reabsorption, leading to suppression of renin levels [28]. Moreover, primary aldosteronism, the prototypical example of low-renin hypertension, has been acknowledged as the most frequent form of secondary hypertension [29].

Differential diagnosis of low renin forms of hypertension is clinically relevant, because different forms are treated with different therapies. A practical classification of low-renin hypertensive states is based on aldosterone levels [16] ( $\bullet$ Table 1). A close examination of clinical and pathophysiological features of these disorders is beyond the purpose of this review, and has been reported elsewhere [16]. Coexistence of low levels of both renin and aldosterone can be due to acquired or congenital disorders. Acquired causes encompass drugs, which suppress renin and therefore aldosterone secretion ( $\beta$-blockers, central anti-adrenergic drugs such as clonidine and $\alpha$-methyl-DOPA, nonsteroidal antiinflammatory drugs and COX-2 inhibitors, unfractionated heparin) [30-32], conditions of significant reduction in nephron mass (chronic glomerulonephritis, diabetic nephropathy, unilateral nephrectomy or, simply, ageing) [16], or activation of mineralocorticoid receptors (MRs) by steroids different from aldosterone. This latter is the case of the "Apparent Mineralocorticoid Excess Syndrome" (AMES), in which an excessive licorice intake can suppress the physiologic activity of $11 \beta$-hydroxysteroid dehydrogenase type 2 (11ßHSD2). Such inactivation prevents the conversion of circulating cortisol to cortisone, and cortisol can then act as a mineralocorticoid hormone [33]. This same result may occur with a primary cortisol excess in Cushing's syndrome (especially with ectopic ACTH production, for the higher levels of cortisol produced) [34]. An adrenal tumor secreting deoxycorticosterone (DOC), an aldosterone precursor with mineralocorticoid properties, is an alternative but is a much rarer occurrence of MR activation by steroids different from aldosterone.

Among genetic disorders with low levels of both renin and aldosterone, those with BP elevation mediated by extrinsic activation of MRs can be distinguished from those whose hypertension is due to alterations downstream from the MR. These latter include constitutive activation of MRs [35] and Liddle's syndrome, that is due to an increased activity of the epithelial sodium channel (ENaC), the main renal effector of MRs [36]. Both of these disorders do not respond to MR-antagonists, but respond well to amiloride, that directly blocks ENaC. Genetic disorders leading to the increased activation of MRs, include congenital AMES, the syndrome of glucocorticoid resistance, and the rarer forms of congenital adrenal hyperplasia (CAH) associated with a functional deficit of $11 \beta$-hydroxylase and $17 \alpha$-hydroxylase. In all these diseases, MR activation is due to an excess of a hormone with mineralocorticoid properties that is different from aldosterone, but whose binding to MRs can be prevented by MR-antagonists. In congenital AMES, an inactivating mutation in the gene for $11 \beta \mathrm{HSD} 2$ causes an intracellular cortisol excess that results in its inappropriate binding to the MR [37]. In the syndrome of glucocorticoid resistance, the glucocorticoid receptor does not respond to cortisol and does not mediate pituitary feedback regulation of $\mathrm{ACTH}$ : this results in an excessive stimulation of the adrenals and an increased production of cortisol and of others adrenal steroids with saltretaining activity [38]. Finally, a deficit of $11 \beta$-hydroxylase or $17 \alpha$-hydroxylase blocks cortisol production and elicits ACTH excess that drives the overproduction of DOC $[39,40]$.

Besides low-renin essential hypertension, normal levels of aldosterone in the presence of low renin are found in Gordon's syndrome, a genetically determined disorder of sodium and potassium transport in the distal renal tubule $[41,42]$. This syndrome is characterized by an abnormally high reabsorption of both sodium and potassium, leading to hyperkalemia and hypervolemia, and by a remarkable responsiveness to thiazide diuretics. Usually, sodium and potassium balances have reciprocal effects on aldosterone secretion, so that aldosterone is maintained in the normal range. Variations in dietary sodium intake and diuretic therapy can alter aldosterone production, and patients with Gordon's syndrome may show even reduced or increased aldosterone levels [43].

Primary aldosteronism (PA) may even present, in milder forms, with low renin coupled with inappropriately high-normal levels of aldosterone, although very high levels of aldosterone that are renin-independent constitute the characteristic feature of this disorder. Diagnosis of PA entails 3 steps, namely a screening test, a confirmation/exclusion test to definitively distinguish it from low-renin essential hypertension, and subtype classification to recognize familial forms and separate unilateral from bilateral disease [44]. An early and accurate diagnosis of PA is important both for its prevalence and its clinical impact. In fact, PA accounts for $4.3 \%$ of hypertensives in the general population and up to 9.5\% in referral centers [45]; moreover, PA patients show a higher risk of cardiovascular events in comparison to essential hypertension, and this excess risk may be completely reverted with a targeted therapy $[46,47]$. Subtype classification of PA is key in determining the appropriate therapy. In fact, whereas a particular familial form, glucocorticoid-remediable aldosteronism, requires a treatment with low-dose glucocorticoids, bilateral forms (bilateral adrenal hyperplasia) are best treated medically with MRBs and unilateral forms (mainly aldosteroneproducing adenoma) may be surgically cured by unilateral adrenalectomy [44].

\section{Renin Levels as a Predictor of Response to Different Antihypertensive Drug Regimens \\ $\nabla$}

\section{Variability of response to different anti-hypertensive} drug classes

Heterogeneity of $\mathrm{BP}$ response to different antihypertensive agents is well-known among clinicians [48]. It was first recognized when earlier studies with diuretics and $\beta$-blockers reported a differential response to these drugs among hypertensive people [49-52]. Such variability of response was later con- 
Table 2 Classification of antihypertensive drugs according to Laragh's hypothesis.

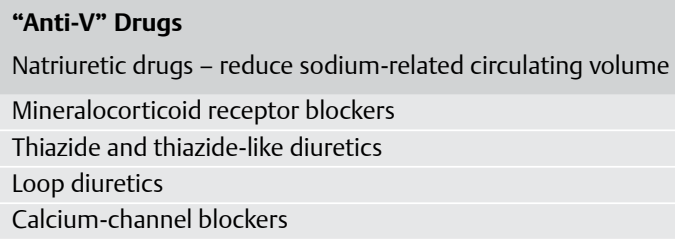

“Anti-V” Drugs, “Anti-R” Drugs: see text. Modified and adapted from [64]

\author{
“Anti-R" Drugs \\ Anti-renin/Angiotensin-II drugs - reduce renin/angiotensin-II related vasoconstriction \\ Drugs suppressing renin activity \\ Centrally acting $\alpha_{2}$-adrenergic receptor agonists \\ $\beta$-Adrenergic receptor blockers \\ Direct renin inhibitors \\ Drugs preventing angiotensin-II production or effects \\ Angiotensin-converting enzyme inhibitors \\ Angiotensin-II receptor blockers
}

firmed also with other antihypertensive drug classes, such as ACEi and calcium channel blockers (CCBs) [53-59]. A milestone study by Materson and colleagues [55], in particular, compared the response to 6 different anti-hypertensive drugs and to placebo in a wide population of white and black men. This randomized trial observed a strong variability in response to several drugs across different ethnic groups and ages. This then allowed the formulation of an "age-race rule" that was proposed as a guide to initial choice of antihypertensive treatment [48]. Materson's observations were somehow confirmed by subsequent prospective cross-over studies performed by Brown and colleagues $[56,57]$. The study population considered was young (aged less than 55 years) with a net prevalence of Caucasian people. In these trials, they observed larger BP decrease with ACEi and $\beta$-blockers and a consistence of individual response to ACEi and $\beta$-blockers and to CCBs and thiazide diuretics, but not in other pairs of drugs. Combining these results with those of previous studies $[55,60]$ and, in particular, considering the findings of the ALLHAT study [58], Brown developed an algorithm, termed the "AB/CD-rule" from the capital letters of the main antihypertensive drug classes considered [61], that quickly summarized our knowledge about defined correlations between demographic characteristics and $\mathrm{BP}$ response to initial different drugs. According to the "AB/CD-rule", the initial antihypertensive drug should be chosen between an ACEi, an ARB or a $\beta$-blocker (one from the "A-B" pair) in younger (i.e., < 55 years old) Caucasian people and between a CCB or a thiazide diuretic (one from the "C-D" pair) in black or older ( > 55 years old) Caucasian patients.

\section{Pathophysiological basis of BP response variability to different antihypertensive drugs - the Laragh's hypothesis}

The pathophysiological bases of BP response variability had been first investigated by Bühler, Laragh and colleagues, who observed a strong correlation between renin levels (determined as plasma renin activity) and the pattern of response to different antihypertensive drugs. In fact, people with medium or high renin activity showed a striking response to propranolol, a $\beta$-blocker, whereas people with low renin activity did not show a clinically significant BP reduction with this drug [49]. Rather, low-renin hypertension was observed to respond better to diuretics [62].

On this basis, Laragh postulated that all hypertensive disorders are due to a variable contribution of renin-dependent vasoconstriction and sodium-related circulating volume expansion. RAAS profiling was then proposed to define which - if any - of these 2 factors is predominant in sustaining BP elevation [63].
According to this "vasoconstriction-volume model", all the antihypertensive drugs should somehow counteract one of the hypertension determining factors, either excessive vascular resistance (the "R-factor") or expanded circulating volume (the "V-factor"). Antihypertensive agents may be therefore classified as "anti-R" or "anti-V" drugs [64] (๑ Table 2).

Over the years, refining their observations, Laragh and colleagues developed a renin-based method to guide the choice of antihypertensive therapy [64] ( $\bullet$ Fig. 1). When renin activity falls into medium- to high-levels (PRA $\geq 0.65 \mathrm{ng} / \mathrm{ml} / \mathrm{h}$ ) then an "anti-R" drug is indicated; with suppressed renin levels (PRA $<0.65 \mathrm{ng} / \mathrm{ml} / \mathrm{h}$ ), instead, therapy should begin with an "anti-V" drug. If necessary, dose has to be increased to a maximal level. When BP is not controlled on monotherapy, then renin profiling can again be useful to investigate the current pathophysiological response to the initial therapy in the individual patient. In this case, suppressed renin levels indicate the need to add an "anti-V" drug. This is aimed at boosting the natriuretic effect in patients firstly already treated with an "anti-V" drug, and at balancing a residual action of the "V-factor" in patients previously treated with an "anti-R" drug. On the contrary, an unsuppressed PRA again indicates the need to add an "anti-R" drug. This allows to strengthen the anti-renin effect in patients firstly treated with an "anti-R" drug, and to counteract a concurrent action of the "R-factor" in people previously treated with an "anti-V" drug. To this end, considering that anti-RAAS agents manage in reducing about $90 \%$ of RAAS activity and that PRA assays measure renin enzymatic activity, it is important to underline the effect of different "anti-R" drugs on PRA levels. In fact, during therapy with agents that suppress renin secretion or inhibit its enzymatic activity (namely, centrally-acting antiadrenergic drugs, $\beta$-blocker and direct renin inhibitors), the cutoff to distinguish unsuppressed and suppressed PRA levels remains $0.65 \mathrm{ng} / \mathrm{ml} / \mathrm{h}$. With agents which inhibit angiotensin-II production or block its effects (ACEi and ARBs), the cutoff is ten-fold, $6.5 \mathrm{ng} / \mathrm{ml} / \mathrm{h}$, because the reactive increase in PRA levels along with the blockade of the downstream elements of the RAAS, that reduces the effective activity of the system to about $10 \%$ of the observed values [65].

\section{Clinical confirmation and current controversies of Laragh's hypothesis}

Whilst Laragh developed his theory, many other authors investigated the pathophysiological bases of BP response variability to antihypertensive agents. Several observational studies confirmed the predictive value of renin levels to the response to $\beta$-blockers, thiazide diuretics, and mineralocorticoid receptorblockers (for a review of these studies, see [66]). Other reports, 


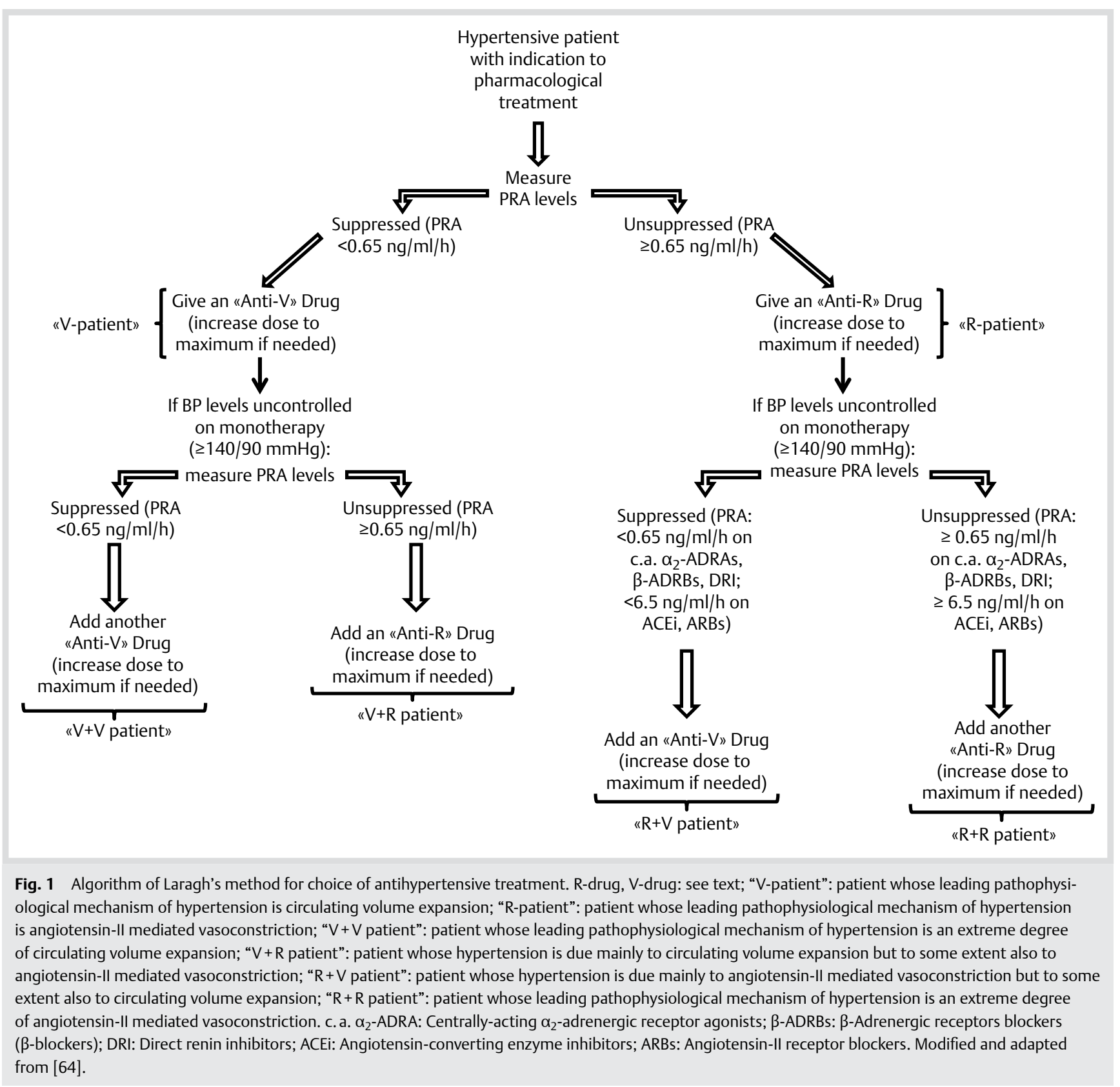

however, failed to observe an association between pre-treatment renin levels and response to $\beta$-blockers and/or diuretics [67-70].

Later, a number of studies investigated the association between pre-treatment renin profiling and response to anti-hypertensive drug classes other than $\beta$-blockers and diuretics. In a randomized trial, Weir et al. observed a lack of correlation between $\mathrm{BP}$ reduction and pre-treatment renin levels in a cohort of predominately low-renin African-American hypertensives treated with trandolapril [71]. Another trial, however, reported a superior efficacy of $\beta$-blockers and ACEi in a population of young white patients in which PRA levels were associated to BP response to ACEi [56]. More recently, 2 small observational studies have also reported an association between pre-treatment renin levels and response to ARBs, considering not only office BP but also ambulatory BP monitoring [72,73].

In 1998, Preston et al. published a post-hoc analysis on the data of the large study previously conducted by Materson, aiming at comparing renin profiling to the "age-race rule". In this study, the $\mathrm{BP}$ response to a therapy appropriate to renin levels resulted not superior to the one obtained by an antihypertensive therapy fitting to age and ethnic group. The authors then concluded that the "age-race rule", simpler and cheaper than renin profiling, was preferable as a guide to clinical decision-making [48]. Although a correlation through renin activity and age and ethnic group has been recognized for long time $[9,74]$, this correlation is not strict enough to allow an accurate prediction of renin levels on the basis of demographic data alone [10]. Moreover, the "age-race" rule is no more able to predict the response to a new antihypertensive agent when an antihypertensive therapy is already ongoing [64]. In fact, in subsequent observational studies, a head-to-head comparison of the "age-race rule" and renin profiling overturned the conclusions by Preston and colleagues. Schwartz et al. observed that renin profiling alone was superior to the "age-race rule" alone in predicting BP response to a therapy with candesartan or hydrochlorothiazide [75]. In an inter- 
esting study, Turner et al. retrieved renin levels as the only parameter, beside pre-treatment BP, consistently able to predict systolic and diastolic response to both atenolol and hydrochlorothiazide, whatever the age and the ethnic group. Moreover, this study observed for the first time an association between intreatment renin levels and response to add-on therapy [76]. Renin levels were also the only parameter significantly predictive of response to each of the 4 drugs used (bisoprolol, losartan, hydrochlorothiazide, and amlodipine) in a recent randomized cross-over trial that investigated laboratory predictors of BP reduction [77]. On the contrary, another recent trial conducted in elderly ( $>70$ years old) hypertensive patients failed to recognize an association between renin levels and BP response to valsartan and/or hydrochlorotiazide [78], whereas a recent observational study retrieved a significant association between renin levels and diastolic BP response and a trend towards an association between renin levels and systolic PB response [79]. On the whole, the studies so far presented reached conflicting conclusions about the predictive value of renin profiling: reasons for such an inconsistency have not been fully understood. A possible explanation can be suggested due to lack of appropriate control, in many of these studies, for concomitant medications such as non-steroidal anti-inflammatory drugs (NSAIDs), which heavily interfere with the RAAS affecting the response to anti-hypertensive therapy. Another explanation could reside in a differential activity of tissue-specific RAAS and systemic RAAS in the single patient: while, in fact, plasma renin activity may not accurately account for the level of activation of tissue-specific RAAS, it has been shown in animal models that selective activation of central nervous system-RAAS can produce an increase in systemic BP [5]. This latter point apparently challenges the theoretical basis of Laragh's method, even if it is based mainly on data derived from animal models. It should be noted that Laragh's pathophysiological classification of hypertensive phenotypes represents mainly a clinical classification. Its purpose is to suggest a rational approach to guide therapy in a field that is mainly empirical, although is potentially oversimplified. For example, the original Laragh's classification of antihypertensive drugs included reserpine as an "anti-R drug" and $\alpha 1$-adrenergic receptor blockers and direct vasodilators as "antiV drugs" whereas available evidence in the literature do not support such a characterization.

It should be highlighted that to date only a small unblinded randomized trial has been performed to specifically investigate the validity of Laragh's hypothesis [80]. In this study, a group of patients whose therapy was adjusted strictly according to Laragh's method (renin-test guided therapy, RTGT) was compared to a group committed to clinical hypertension specialists care (CSHC). After follow-up, RTGT group, in comparison to CHSC group, showed a significant reduction in systolic BP, a trend towards a reduction of diastolic BP and a higher BP control rate, with no difference in the number of antihypertensive medications (which were the same as baseline) [80].

These data are not fully conclusive: a definite validation of "Laragh's method" should require a large, randomized clinical trial encompassing both naïve hypertensives and already-treated, uncontrolled patients. For this reason, one of the main concerns raised relates to the economic cost of renin levels determination [48]. To this end, some authors have reported an estimate of costs related to the application of renin-profiling in the initial examination of hypertensive patients [19,81], and observed that renin levels determination is quite cheap and warrants savings from an economic point of view. A more extensive cost-effectiveness study has been recently performed [82], suggesting that a renin-guided strategy may be cost-effective, at least for treated but uncontrolled patients, and could be even advantageous in all hypertensive patients if renin testing costs should decrease.

Although heterogeneity in BP response to different drugs has been thoroughly investigated and is a matter of fact, lack of a conclusive validation of Laragh's method has prevented its acknowledgement by many current national and international guidelines for the management of arterial hypertension [83,84]. The British Hypertension Society (BHS) - National Institute for Clinical Excellence (NICE) guidelines, however, early recognized the work by Brown and colleagues, so that since 2004, BHS-NICE guidelines recommend, for the uncomplicated hypertensive patients and in absence of compelling indications and contraindications, a choice of the initial antihypertensive therapy based on the " $\mathrm{AB} / \mathrm{CD}$ rule" [85]. This one, in the light of the broadening evidence [86-88], has been later reduced to the "ACD rule" after the removal of $\beta$-blockers as first-line choice drugs [89]. BHSNICE guidelines at the moment do not recommend renin profiling to guide the choice of therapy, relying only on demographic parameters. Nonetheless, they openly refer to Laragh's "vasoconstriction-volume model" as the main conceptual framework necessarily subtended to the individual variability in BP response to different drugs, and they assume the "age-race model" as an estimate of renin profiling [85]. Recently, even the recent report of the Eighth Joint National Committee (JNC-VIII) moved towards the acknowledgement of differential response to diverse antihypertensive agents and the personalization of therapy, accepting the evidence coming from subgroup analyses of the ALLHAT study [90] and the ASCOT-BPLA study [59]. Therefore, now the JNC-VIII guidelines recommend specifically a CCB or a thiazide diuretic for initial antihypertensive therapy among black people. In conclusion, current evidence reports some observations which are consistent with the pathophysiological basis of Laragh's method $[56,57,77,91]$ and even suggests that RAAS profiling may be useful for management of essential hypertension $[75,76,79]$, especially in complex situations with uncontrolled hypertension not responding to multitherapy [80]. At present, Laragh's method offers a "conceptual framework" that, supplemented with the global clinical picture, may guide clinical reasoning and decision-making in the single patient.

\section{Conclusions}

$\nabla$

More than a century of experimental and clinical studies have recognized the central role of the renin-angiotensin-aldosterone system in regulation of hemodynamics and to classify different patterns of RAAS-profile. Along with clinical features and the epidemiologic context, RAAS profiling may orient towards diagnosis of specific forms of secondary hypertension characterized by a selective responsiveness to targeted therapies [16]. In particular, RAAS profiling allows the identification of primary aldosteronism, the most prevalent form of secondary hypertension, whose early diagnosis and targeted treatment is key to effectively reduce the cardiovascular excess risk for which this adrenal disorder is responsible [46,47]. Moreover, some data regarding essential hypertension suggests that RAAS profiling has the opportunity to clarify the main pathophysiological alter- 
ations in the single patient and to guide clinical decision-making [75], especially in complex situations with uncontrolled hypertension not responding to multitherapy [80]. Although Laragh's method requires more extensive validation, it already represents a valuable "conceptual framework" for the hypertension specialist, establishing a connection between pathophysiology and clinics.

\section{Conflict of Interest}

$\nabla$

The authors declare no conflict of interest.

\section{References}

1 Basso N, Terragno NA. History About the Discovery of the Renin-Angiotensin System. Hypertension 2001; 38: 1246-1249

2 Castrop H, Höcherl K, Kurtz A, Schweda F, Todorov V, Wagner C. Physiology of kidney renin. Physiol Rev 2010; 90: 607-673

3 Paul M, Poyan Mehr A, Kreutz R. Physiology of local renin-angiotensin systems. Physiol Rev 2006; 86: 747-803

4 Weir MR, Dzau VJ. The Renin-Angiotensin-Aldosterone System: A Specific Target for Hypertension Management. Am J Hypertens 1999; 12: 205S-213S

5 Takahashi $\mathrm{H}$. Upregulation of the Renin-Angiotensin-AldosteroneOuabain System in the Brain Is the Core Mechanism in the Genesis of All Types of Hypertension. Int J Hypertens 2012, 242786

6 Gavras H, Brunner HB, Vaughan ED, Laragh JH. Angiotensin-sodium interaction in blood pressure maintenance of renal hypertensive and normotensive rats. Science 1973; 180: 1369-1371

7 Laragh $J \mathrm{H}$. Vasoconstriction-volume analysis for understanding and treating hypertension: the use of renin and aldosterone profiles. Am J Med 1973; 55: 261-274

8 Luetscher JA, Boyers DG, Cuthbertson JG, McMahon DF. A model of the human circulation. Regulation by autonomic nervous system and renin-angiotensin system, and influence of blood volume on cardiac output and blood pressure. Circ Res 1973; 32: 84-98

9 Brunner HR, Sealey JE, Laragh JH. Renin subgroups in essential hypertension. Further analysis of their pathophysiological and epidemiological characteristics. Circ Res 1973; 32: 99-105

10 Alderman $M H$, Cohen HW, Sealey JE, Laragh JH. Plasma renin activity levels in hypertensive persons: their wide range and lack of suppression in diabetic and in most elderly patients. Am J Hypertens 2004; 17: $1-7$

11 Brunner HR, Laragh JH, Baer L, Newton MA, Goodwin FT, Krakoff LR, Bard RH, Bühler FR. Essential hypertension: renin and aldosterone, heart attack and stroke. N Engl J Med 1972; 286: 441-449

12 Alderman MH, Madhavan S, Ooi WL, Cohen H, Sealey JE, Laragh JH. Association of the renin-sodium profile with the risk of myocardial infarction in patients with hypertension. N Engl J Med 1991; 324: 1098-1104

13 Gonzalez MC, Cohen HW, Sealey JE, Laragh JH, Alderman MH. Enduring direct association of baseline plasma renin activity with all-cause and cardiovascular mortality in hypertensive patients. Am J Hypertens 2011; 24: 1181-1186

14 Tomaschitz A, Pilz S, Ritz E, Morganti A, Grammer T, Amrein K, Boehm $B O$, März W. Associations of plasma renin with 10 -year cardiovascular mortality, sudden cardiac death, and death due to heart failure. Eur Heart J 2011; 32: 2642-2649

15 Morimoto A, Uzu T, Fujii T, Nishimura M, Kuroda S, Nakamura S, Inenaga T, Kimura G. Sodium sensitivity and cardiovascular events in patients with essential hypertension. Lancet 1997; 350: 1734-1737

16 Mulatero $P$, Verhovez A, Morello F, Veglio F. Diagnosis and treatment of low-renin hypertension. Clin Endocrinol (Oxf) 2007; 67: 324-334

17 Verhovez A, Mulatero P, Bertello C, Saglio E, Viola A, Tosello F, Rabbia $F$, Veglio F. Is Renin-Based Treatment a Reasonable Strategy to Treat Essential Hypertension? High Blood Press Cardiovasc Prev 2008; 15: $1-5$

18 Spence JD. Stepped care for hypertension is dead, but what will replace it? CMAJ 1989; 140: 1133-1136

19 Spence JD. Government guidelines for treatment of hypertension. Am J Hypertens 1995; 8: 541

20 Garovic VD, Textor SC. Renovascular hypertension and ischemic nephropathy. Circulation 2005; 112: 1362-1374
21 Song $A L$, Zeng ZP, Tong $A L$, Lu L, Chen S, Li M, Fu CL, Wang YH, Sun ML. Differences of blood plasma renin activity, angiotensin II and aldosterone levels in essential or secondary hypertension. (Article in Chinese) Zhonghua Nei Ke Za Zhi 2012; 51: 294-298

22 Bernini M, Bacca A, Casto G, Carli V, Cupisti A, Carrara D, Farnesi I, Barsotti G, Naccarato AG, Bernini G. A case of pheochromocytoma presenting as secondary hyperaldosteronism, hyperparathyroidism, diabetes and proteinuric renal disease. Nephrol Dial Transplant 2011; 26: $1104-1107$

23 Laragh JH. Oral contraceptives - induced hypertension - nine years later. Am J Obstet Gynecol 1976; 126: 141-147

24 McVicar M, Carman C, Chandra M, Abbi RJ, Teichberg S, Kahn E. Hypertension secondary to renin-secreting juxtaglomerular cell tumor: case report and review of 38 cases. Pediatr Nephrol 1993; 7: 404-412

25 Muller FB, Sealey JE, Case DB, Atlas SA, Pickering TG, Pecker MS, Preibisz $J J$, Laragh $J H$. The captopril test for identifying renovascular disease in hypertensive patients. Am J Med 1986; 80: 633-644

26 Rossi GP, Pavan E, Chiesura-Corona M, Bader M, Paganini G, Cesari M, De Toni R, Feltrin GP, Ganten D, Pessina AC. Renovascular hypertension with low-to-normal plasma renin: clinical and angiographic features. Clin Sci (Lond) 1997; 93: 435-443

27 Lenz T, Kia T, Rupprecht G, Schulte KL, Geiger H. Captopril test: time over? J Hum Hypertens 1999; 13: 431-435

28 Lifton RP, Gharavi AG, Geller DS. Molecular mechanisms of human hypertension. Cell 2001; 104: 545-556

29 Omura M, Saito J, Yamaguchi K, Kakuta Y, Nishikawa T. Prospective study on the prevalence of secondary hypertension among hypertensive patients visiting a general outpatient clinic in Japan. Hypertens Res 2004; 27: 193-202

30 Mulatero P, Rabbia F, Milan A, Paglieri C, Morello F, Chiandussi L, Veglio $F$. Drug effects on aldosterone/plasma renin activity ratio in primary aldosteronism. Hypertension 2002; 40: 897-902

31 Gordon RD, Laragh JH, Funder JW. Low renin hypertensive states: perspectives, unsolved problems, future research. Trends Endocrinol Metab 2005; 16: 108-113

32 Sealey JE, Gerten JN, Ledingham JG, Laragh JH. Inhibition of renin by heparin. J Clin Endocrinol Metab 1967; 27: 699-705

33 Quinkler M, Stewart PM. Hypertension and the cortisol-cortisone shuttle. J Clin Endocrinol Metab 2003; 88: 2384-2392

34 Cicala MV, Mantero F. Hypertension in Cushing's syndrome: from pathogenesis to treatment. Neuroendocrinology 2010; 92: 44-49

35 Geller DS, Farhi A, Pinkerton N, Fradley M, Moritz M, Spitzer A, Meinke $G$, Tsai FT, Sigler PB, Lifton RP. Activating mineralocorticoid receptor mutation in hypertension exacerbated by pregnancy. Science 2000; 289: $119-123$

36 Warnock DG. Liddle syndrome: an autosomal dominant form of human hypertension. Kidney Int 1998; 53: 18-24

37 Wilson RC, Nimkarn S, New MI. Apparent mineralocorticoid excess. Trends Endocrinol Metab 2001; 12: 104-111

38 Stratakis CA, Karl M, Schulte HM, Chrousos GP. Glucocorticosteroid resistance in humans. Elucidation of the molecular mechanisms and implications for pathophysiology. Ann N Y Acad Sci 1994; 746: 362-376

39 Zachmann $M$, Tassinari D, Prader A. Clinical and biochemical variability of congenital adrenal hyperplasia due to 11 beta-hydroxylase deficiency. A study of 25 patients. J Clin Endocrinol Metab 1983; 56: 222-229

40 Takeda Y, Yoneda T, Demura M, Furukawa K, Koshida H, Miyamori I. Mabuchi H. Genetic analysis of the cytochrome P-450c17alpha (CYP17) and aldosterone synthase (CYP11B2) in Japanese patients with 17alpha-hydroxylase deficiency. Clin Endocrinol (Oxf) 2001; 54: 751-758

41 Hadchouel J, Delaloy C, Fauré S, Achard JM, Jeunemaitre X. Familial hyperkalemic hypertension. J Am Soc Nephrol 2006; 17: 208-217

42 Boyden LM, Choi M, Choate KA, Nelson-Williams CJ, Farhi A, Toka HR, Tikhonova IR, Bjornson R, Mane SM, Colussi G, Lebel M, Gordon RD, Semmekrot BA, Poujol A, Välimäki MJ, De Ferrari ME, Sanjad SA, Gutkin $M$, Karet FE, Tucci JR, Stockigt JR, Keppler-Noreuil KM, Porter CC, Anand SK, Whiteford ML, Davis ID, Dewar SB, Bettinelli A, Fadrowski JJ, Belsha CW, Hunley TE, Nelson RD, Trachtman H, Cole TR, Pinsk M, Bockenhauer $D$, Shenoy M, Vaidyanathan P, Foreman JW, Rasoulpour M, Thameem F, Al-Shahrouri HZ, Radhakrishnan J, Gharavi AG, Goilav B, Lifton RP. Mutations in kelch-like 3 and cullin 3 cause hypertension and electrolyte abnormalities. Nature 2012; 482: 98-102

43 Stowasser M, Pimenta E, Gordon RD. Familial or genetic primary aldosteronism and Gordon syndrome. Endocrinol Metab Clin North Am 2011; 40: 343-368 
44 Funder JW, Carey RM, Fardella C, Gomez-Sanchez CE, Mantero F, Stowasser M, Young WF Jr, Montori VM.Endocrine Society. Case detection, diagnosis, and treatment of patients with primary aldosteronism: an endocrine society clinical practice guideline. J Clin Endocrinol Metab 2008; 93: 3266-3281

45 Hannemann A, Wallaschofski $H$. Prevalence of primary aldosteronism in patient's cohorts and in population-based studies - a review of the current literature. Horm Metab Res 2012; 44: 157-162

46 Catena C, Colussi G, Nadalini E, Chiuch A, Baroselli S, Lapenna R, Sechi LA. Cardiovascular outcomes in patients with primary aldosteronism after treatment. Arch Intern Med 2008; 168: 80-85

47 Mulatero P, Monticone S, Bertello C, Viola A, Tizzani D, Iannaccone A, Crudo V, Burrello J, Milan A, Rabbia F, Veglio F. Long-term cardio- and cerebrovascular events in patients with primary aldosteronism. J Clin Endocrinol Metab 2013; 98: 4826-4833

48 Preston RA, Materson BJ, Reda DJ, Williams DW, Hamburger RJ, Cushman $W C$, Anderson RJ. Age-race subgroup compared with renin profile as predictors of blood pressure response to antihypertensive therapy. Department of Veterans Affairs Cooperative Study Group on Antihypertensive Agents. JAMA 1998; 280: 1168-1172

49 Bühler FR, Laragh JH, Baer L, Vaughan ED Jr, Brunner HR. Propranolol inhibition of renin secretion. A specific approach to diagnosis and treatment of renin-dependent hypertensive diseases. N Engl J Med 1972; 287: 1209-1214

50 Adlin EV, Marks AD, Channick BJ. Spironolactone and hydrochlorothiazide in essential hypertension. Blood pressure response and plasma renin activity. Arch Intern Med 1972; 130: 855-858

51 Bühler FR, Burkart F, Lütold BE, Küng M, Marbet G, Pfisterer M. Antihypertensive beta blocking action as related to renin and age: a pharmacologic tool to identify pathogenetic mechanisms in essential hypertension. Am J Cardiol 1975; 36: 653-669

52 Stumpe KO, Overlack 0 . Diuretics, beta-blockers or both as treatment for essential hypertension. Br J Clin Pharmacol 1979; 7: 189S-197S

53 Veterans Administration Co-operative Study Group On Antihypertensive Agents. Racial differences in response to low-dose captopril are abolished by the addition of hydrochlorothiazide. Br J Clin Pharmacol 1982; 14: 97S-101S

54 Saunders E, Weir MR, Kong BW, Hollifield J, Gray J, Vertes V, Sowers JR, Zemel MB, Curry C, Schoenberger J, Wright JT, Kirkendall W, Conradi $E C$, Jenkins P, McLean B, Massie B, Berenson G, Flamenbaum W. A comparison of the efficacy and safety of a beta-blocker, a calcium channel blocker, and a converting enzyme inhibitor in hypertensive blacks. Arch Intern Med 1990; 150: 1707-1713

55 Materson BJ, Reda DJ, Cushman WC, Massie BM, Freis ED, Kochar MS, Hamburger RJ, Fye C, Lakshman R, Gottdiener J, Ramierz EA, Henderson WG for the Department of Veterans Affairs Cooperative Study Group on Antihypertensive Agents. Single-drug therapy for hypertension in men. A comparison of six antihypertensive agents with placebo. N Engl J Med 1993; 328: 914-921

56 Dickerson JE, Hingorani AD, Ashby MJ, Palmer CR, Brown MJ. Optimisation of antihypertensive treatment by crossover rotation of four major classes. Lancet 1999; 353: 2008-2013

57 Deary AJ, Schumann AL, Murfet H, Haydock SF, Foo RS, Brown MJ. Double-blind, placebo-controlled crossover comparison of five classes of antihypertensive drugs. J Hypertens 2002; 20: 771-777

58 ALLHAT Officers and Coordinators for the ALLHAT Collaborative Research Group. The Antihypertensive and Lipid-Lowering Treatment to Prevent Heart Attack Trial. Major outcomes in high-risk hypertensive patients randomized to angiotensin-converting enzyme inhibitor or calcium channel blocker vs diuretic: The Antihypertensive and LipidLowering Treatment to Prevent Heart Attack Trial (ALLHAT). JAMA 2002; 288: 2981-2997

59 Gupta AK, Poulter NR, Dobson J, Eldridge S, Cappuccio FP, Caulfield M, Collier D, Cruickshank JK, Sever PS, Feder G, ASCOT. Ethnic differences in blood pressure response to first and second-line antihypertensive therapies in patients randomized in the ASCOT Trial. Am J Hypertens 2010; 23: 1023-1030

60 Philipp T, Anlauf M, Distler A, Holzgreve H, Michaelis J, Wellek S. Randomised, double blind, multicentre comparison of hydrochlorothiazide, atenolol, nitrendipine, and enalapril in antihypertensive treatment: results of the HANE study. HANE Trial Research Group. BMJ 1997; 315: 154-159

61 Brown MJ, Cruickshank JK, Dominiczak AF, MacGregor GA, Poulter NR, Russell GI, Thom S, Williams B. Executive Committee, British Hypertension Society. Better blood pressure control: how to combine drugs. J Hum Hypertens 2003; 17: 81-86
62 Vaughan ED Jr, Laragh JH, Gavras I, Bühler FR, Gavras H, Brunner HR, Baer $L$. Volume factor in low and normal renin essential hypertension. Treatment with either spironolactone or chlorthalidone. Am J Cardiol 1973; 32: 523-532

63 Laragh JH, Baer L, Brunner HR, Buhler FR, Sealey JE, Vaughan ED Jr. Renin, angiotensin and aldosterone system in pathogenesis and management of hypertensive vascular disease. Am J Med 1972; 52: 633-652

64 Laragh JH, Sealey JE. The plasma renin test reveals the contribution of body sodium-volume content $(\mathrm{V})$ and renin-angiotensin $(\mathrm{R})$ vasoconstriction to long-term blood pressure. Am J Hypertens 2011; 24: $1164-1180$

65 Sealey JE, Parra D, Rosenstein R, Laragh JH. "Effective" plasma renin activity: a derived measure for assessing residual plasma renin activity in patients taking angiotensin-converting enzyme inhibitors or angiotensin receptor blockers. Hypertension 2010; 55: e16

66 Cody RJ, Laragh JH, Case DB, Atlas SA. Renin system activity as a determinant of response to treatment in hypertensionand heart failure. Hypertension 1983; 5: III36-III42

67 Woods JW, Pittman AW, Pulliam CC, Werk EE Jr., Waider W, Allen CA. Renin profiling in hypertension and its use in treatment with propranolol and chlorthalidone. N Engl J Med 1976; 294: 1137-1143

68 Pedersen EB, Kornerup HJ. Plasma renin concentration in essential hypertension during beta-adrenergic blockade and vasodilator therapy. Eur J Clin Pharmacol 1977; 12: 93-96

69 Nilsson OR, Karlberg BE, Ohlsson O, Thulin T, Tolagen K. Atenolol administered once daily in primary hypertension. Effects on blood pressure in relation to pre-treatment plasma renin activity. Acta Med Scand 1979; 206: 303-308

70 Wyndham RN, Gimenez L, Walker WG, Whelton PK, Russell RP. Influence of renin levels on the treatment of essential hypertension with thiazide diuretics. Arch Intern Med 1987; 147: 1021-1025

71 Weir MR, Saunders E. Renin status does not predict the anti-hypertensive response to angiotensin-converting enzyme inhibition in AfricanAmericans. Trandolapril Multicenter Study Group. J Hum Hypertens 1998; 12: 189-194

72 Minami J, Ishimitsu T, Matsuoka H. Pretreatment plasma renin activity levels correlate with the blood pressure response to telmisartan in essential hypertension. Am J Hypertens 2008; 21: 10-13

73 Minami J, Ohno E, Furukata S, Ishimitsu T, Matsuoka H. Pretreatment levels of plasma renin activity predict ambulatory blood pressure response to valsartan in essential hypertension. J Hum Hypertens 2009; 23: 683-686

74 Chrysant SG, Danisa K, Kem DC, Dillard BL, Smith WJ, Frohlich ED. Racial differences in pressure, volume and renin interrelationships in essential hypertension. Hypertension 1979; 1: 136-141

75 Schwartz GL, Bailey K, Chapman AB, Boerwinkle E, Turner ST. The role of plasma renin activity, age, and race in selecting effective initial drug therapy for hypertension. Am J Hypertens 2013; 26: 957-964

76 Turner ST, Schwartz GL, Chapman AB, Beitelshees AL, Gums JG, CooperDeHoff RM, Boerwinkle E, Johnson JA, Bailey KR. Plasma renin activity predicts blood pressure responses to beta-blocker and thiazide diuretic as monotherapy and add-on therapy for hypertension. Am J Hypertens 2010; 23: 1014-1022

77 Suonsyrjä T, Hannila-Handelberg T, Paavonen KJ, Miettinen HE, Donner $K$, Strandberg T, Tikkanen I, Tilvis R, Pentikäinen PJ, Kontula $K$, Hiltunen TP. Laboratory tests as predictors of the antihypertensive effects of amlodipine, bisoprolol, hydrochlorothiazide and losartan in men: results from the randomized, double-blind, crossover GENRES Study. J Hypertens 2008; 26: 1250-1256

78 Weintraub HS, Duprez DA, Cushman WC, Zappe DH, Purkayastha D, Samuel $R$, Izzo JL Jr. Antihypertensive response to thiazide diuretic or angiotensin receptor blocker in elderly hypertensives is not influenced by pretreatment plasma renin activity. Cardiovasc Drugs Ther 2012; 26: $145-155$

79 Leotta G, Rabbia F, Testa E, Totaro S, Abram S, Milan A, Mulatero P, Veglio $F$. Efficacy of antihypertensive treatment based on plasma renin activity: An open label observational study. Blood Press 2010; 19: 218-224

80 Egan BM, Basile JN, Rehman SU, Davis PB, Grob CH 3rd, Riehle JF, Walters $C A$, Lackland DT, Merali C, Sealey JE, Laragh JH. Plasma Renin testguided drug treatment algorithm for correcting patients with treated but uncontrolled hypertension: a randomized controlled trial. Am J Hypertens 2009; 22: 792-801

81 Blumenfeld JD, Laragh JH. Renin system analysis: a rational method for the diagnosis and treatment of the individual patient with hypertension. Am J Hypertens 1998; 11: 894-896 
82 Smith SM, Campbell JD. Cost-Effectiveness of Renin-Guided Treatment of Hypertension. Am J Hypertens 2013; 26: 1303-1310

83 Mancia G, Fagard R, Narkiewicz K, Redón J, Zanchetti A, Böhm M, Christiaens T, Cifkova R, De Backer G, Dominiczak A, Galderisi M, Grobbee $D E$, Jaarsma T, Kirchhof $P$, Kjeldsen SE, Laurent S, Manolis AJ, Nilsson $P M$, Ruilope LM, Schmieder RE, Sirnes PA, Sleight P, Viigimaa $M$, Waeber B, Zannad F. Task Force Members. 2013 ESH/ESC Guidelines for the management of arterial hypertension: the Task Force for the management of arterial hypertension of the European Society of Hypertension (ESH) and of the European Society of Cardiology (ESC). J Hypertens 2013; 31: 1281-1357

84 James PA, Oparil S, Carter BL, Cushman WC, Dennison-Himmelfarb C, Handler J, Lackland DT, LeFevre ML, MacKenzie TD, Ogedegbe O, Smith SC Jr, Svetkey LP, Taler SJ, Townsend RR, Wright JT Jr, Narva AS, Ortiz E. 2014 evidence-based guideline for the management of high blood pressure in adults: report from the panel members appointed to the Eighth Joint National Committee (JNC 8). JAMA 2014; 311: 507-520

85 Williams B, Poulter NR, Brown MJ, Davis M, McInnes GT, Potter JF, Sever PS, McG Thom S, British Hypertension Society. Guidelines for management of hypertension: report of the fourth working party of the British Hypertension Society, 2004-BHS IV. J Hum Hypertens 2004; 18 : 139-185

86 Bradley HA, Wiysonge CS, Volmink JA, Mayosi BM, Opie LH. How strong is the evidence for use of beta-blockers as first-line therapy for hypertension? Systematic review and meta-analysis. J Hypertens 2006; 24 : 2131-2141
87 Elliott WJ, Meyer PM. Incident diabetes in clinical trials of antihypertensive drugs: a network meta-analysis. Lancet 2007; 369: 201-207

88 ONTARGET Investigators.Yusuf S, Teo KK, Pogue J, Dyal L, Copland I, Schumacher H, Dagenais G, Sleight P, Anderson C. Telmisartan, ramipril, or both in patients at high risk for vascular events. N Engl J Med 2008; 358: $1547-1559$

89 National Institute for Health and Clinical Excellence - National Clinical Guideline Centre. Clinical Guideline 127. Hypertension - The clinical management of primary hypertension in adults. August 2011. Available at www.nice.org.uk/guidance/CG127 (accessed online on 24 ${ }^{\text {th }}$, March 2014)

90 Leenen FH, Nwachuku CE, Black HR, Cushman WC, Davis BR, Simpson $L M$, Alderman MH, Atlas SA, Basile JN, Cuyjet AB, Dart R, Felicetta JV, Grimm RH, Haywood LJ, Jafri SZ, Proschan MA, Thadani U, Whelton PK, Wright JT, Antihypertensive and Lipid-Lowering Treatment to Prevent Heart Attack Trial Collaborative Research Group. Clinical events in high-risk hypertensive patients randomly assigned to calcium channel blocker versus angiotensin-converting enzyme inhibitor in the antihypertensive and lipid-lowering treatment to prevent heart attack trial. Hypertension 2006; 48: 374-384

91 Alderman $M H$, Cohen HW, Sealey JE, Laragh JH. Pressor responses to antihypertensive drug types. Am J Hypertens 2010; 23: 1031-1037 